\title{
The Current Status of the New World Monkey Phylogeny*
}

\author{
HORACIO SCHNEIDER** \\ Campus Universitário de Bragança, Universidade Federal do Pará, \\ Alameda Leandro Ribeiro, s/n - 68600-000 Bragança, Pará, Brazil \\ Manuscript received on January 31, 2000; accepted for publication on February 2, 2000
}

\begin{abstract}
Four DNA datasets were combined in tandem (6700 bp) and Maximum parsimony and Neighbor-Joining analyses were performed. The results suggest three groups emerging almost at the same time: Atelidae, Pitheciidae and Cebidae. The total analysis strongly supports the monophyly of the Cebidae family, grouping Aotus, Cebus and Saimiri with the small callitrichines. In the callitrichines, the data link Cebuela to Callithrix, place Callimico as a sister group of Callithrix/Cebuella, and show Saguinus to be the earliest offshoot of the callitrichines. In the family Pithecidae, Callicebus is the basal genus. Finally, combined molecular data showed congruent branching in the atelid clade, setting up Alouatta as the basal lineage and Brachyteles-Lagothrix as a sister group and the most derived branch. Two major points remain to be clarified in the platyrrhine phylogeny: (i) what is the exact branching pattern of Aotus, Cebus, Saimiri and the small callitrichines, and (ii), which two of these three lineages, pitheciines, atelines or cebids, are more closely related?
\end{abstract}

Key words: New World monkeys, Platyrrhine, Taxonomy, Molecular, Evolution

\section{INTRODUCTION}

The systematics of New World monkeys has been a subject of strong debate during the last three decades. The main protagonists and their taxonomic proposals are: Simons (1972), Hershkovitz (1977), Rosenberger (1981), Ford (1986), and Kay (1990). All of these proposals are based mainly on morphological or ecological studies. The majority of the authors agree with the existence of three monophyletic clades: the large monkeys with a prehensile tail, a group constituted by Alouatta, Ateles, Lagothrix, and Brachyteles; the seed predator monkeys, consisting of Pithecia, Chiropotes, and Cacajao, and the small clawed monkeys, composed of

\footnotetext{
*Invited paper

** Member of the Academia Brasileira de Ciências

E-mail: hschneider@eletronet.com.br
}

the Saguinus, Leontopithecus, Callithrix, and Cebuella genera. However, they disagree in relation to the branching order among these three major clades, within the ateline and callitrichine clades, and also on the placement of Saimiri, Cebus, Aotus, Callicebus, and Callimico.

Hershkovitz (1977), placed the small Callimico in its own family Callimiconidae, based on its controversial features: this genus shares small body size and the presence of claws instead of nails with the callitrichines, and single pregnancy and the presence of a third molar with the remaining platyrrhine lineages. On the other hand, based on those ambiguous affinities, other morphologists place $\mathrm{Cal}$ limico as the first callitrichine offshoot to diverge from the common ancestor (Rosenberger 1981, Ford 1986, Kay 1990). Cebus and Saimiri are considered 
by Ford (1986) as the earliest offshoot lineages of the New World primate radiation, but Kay (1990), places Cebus as the basal platyrrhine and Saimiri as a sister group of the callitrichines. Conversely, Rosenberger (1981) considers Cebus and Saimiri as sister groups of the callitrichines. The position of the Callicebus genus has been also controversial. According to Kay (1990) Callicebus is the most basal of the callitrichine tree, and Ford (1986) places Callicebus together with Cebus and Saimiri as the most basal clade of the platyrrhines. However, Rosenberger \& Coimbra-Filho (1984) and Rosenberger et al. (1990) argued that Callicebus and Aotus are sister lineages linked to the pitheciine clade. In a more drastic point of view, Tyler (1991) suggested that Aotus must be removed from the ceboid clade and placed in a sister group of the entire Anthropoidea. Supporting this proposal, Tejedor (1998) additionally pointed out that Aotus and Callicebus are ancient taxa and suggested that they have a common ancestor. His belief is based on the assumption that the two Miocene genera, Homunculus and Carlocebus, show many primitive characters shared by both Aotus and Callicebus.

The authors also disagree on the internal arrangements within atelines and callitrichines. In the ateline clade the four genera are arranged in three different ways: Ateles and Brachyteles as sister groups (Rosenberger 1981), Brachyteles, Lagothrix and Ateles in a non-resolved trichotomy (Ford 1986), and two clades composed of Ateles-Lagothrix and Alouatta-Brachyteles (Kay 1990). Inside the callitrichines, most of the authors consider the gumivorous Cebuella and Callitrix as the most derived lineages. For Saguinus and Leontopithecus there are two proposals: one places Leontopithecus as a sister group of Callithrix-Cebuela (Rosenberger 1981) and the other places Saguinus as a sister group of the gumivorous monkeys (Ford 1986, Kay 1990).

\section{THE MOLECULAR DATA}

Molecular data suitable to cladistic analysis of the New World monkeys were first obtained at the be- ginning of the 90's, being the first DNA dataset of aligned sequences of the nuclear epsilon globin gene involving all 16 platyrrhine genera and was published by Schneider et al. (1993). Subsequently, a series of datasets was generated, some including all extant New World primate genera (Schneider et al. 1996, Canavez et al. 1999a, von Dornam \& Ruvolo 1999, Goodman et al. 1998), while others concentrated on particular clades (Canavez et al. 1999b, Chaves et al. 1999, Meireles et al. 1999, Porter et al. 1997a b, Porter et al. 1999, Pastorini et al. 1998, Tagliaro et al. 1997).

Table I summarizes the results involving four nuclear datasets (IRBP, EPSILON, G6PD, and $\beta$ $2 \mathrm{M})$ for all extant New World primates, and additional molecular data ( $\mathrm{vWF}$, upstream region EPSILON, $\gamma$-Globin, ND4, and tRNA) including specific clades. The four DNA datasets (EPSILON, IRBP, G6PD and $\beta$-2M) were combined in tandem to perform a total analysis using Maximum parsimony (MP) and Neighbor-Joining (NJ) approaches utilizing PAUP version 4.0b3a (Swofford, 1998). Figure 1 shows the consensus tree. Percentages at nodes indicate bootstrap support for that particular node, while nodes with stars mean $99-100 \%$ bootstrap support. The branch lengths of the NeighborJoining tree (Saitou \& Nei, 1987) were estimated by the least-squares method referred to in Takezaki et al. (1995). MP and NJ trees were almost identical, differing only in the placement of Aotus. The MP tree placed Aotus as the basal lineage of the Callitrichine clade, while NJ showed Aotus to occur in an unresolved trichotomy with the Cebus-Saimiri clade and the callitrichines.

The four nuclear genes $(\beta-2 \mathrm{M}$, EPSILON, G6PD, and IRBP) analyzed separately are not congruent with regards to the close relationship among the three major clades (pitheciine, ateline, callitrichine). EPSILON and $\beta-2 \mathrm{M}$ support a pitheciineateline clade, whereas G6PD groups the ateline with the callitrichine clade, and IRBP shows the pitheciine clade to be closer to the callitrichine clade. The topology resulting from the total analysis, favors the 
TABLE I

DNA Studies that Elucidate New World monkeys Phylogeny

\begin{tabular}{|c|c|c|c|c|c|c|c|c|}
\hline \multirow{3}{*}{ GENES } & \multirow[b]{2}{*}{$\mathrm{Kb}$} & \multirow[b]{2}{*}{ AUTHORS } & \multirow{2}{*}{$\begin{array}{l}\text { Pitheciine- } \\
\text { Ateline- } \\
\text { Cebid } \\
\text { relationship }\end{array}$} & \multirow[b]{2}{*}{$\begin{array}{l}\text { Aotus, Cebus } \\
\text { and Saimiri } \\
\text { as closely } \\
\text { linked to } \\
\text { callitrichines }\end{array}$} & \multirow[b]{2}{*}{$\begin{array}{l}\text { Callicebus } \\
\text { as basal } \\
\text { genus of the } \\
\text { pitheciine } \\
\text { clade }\end{array}$} & \multirow[b]{2}{*}{$\begin{array}{l}\text { Lagothrix and } \\
\text { Brachyteles } \\
\text { as sister group } \\
\text { in the ateline } \\
\text { clade }\end{array}$} & \multicolumn{2}{|c|}{ Callitrichine clade } \\
\hline & & & & & & & $\begin{array}{c}\text { Saguinus } \\
\text { as basal } \\
\text { genus }\end{array}$ & $\begin{array}{c}\text { Callimico } \\
\text { and } \\
\text { Callithrix as } \\
\text { sister group }\end{array}$ \\
\hline & & & $\mathrm{BS} \%$ & $\mathrm{BS} \%$ & $\mathrm{BS} \%$ & $\mathrm{BS} \%$ & $\mathrm{BS} \%$ & BS\% \\
\hline EPSILON & 1,8 & $\begin{array}{l}\text { Schneider } \text { et al. } \\
1993\end{array}$ & $\mathrm{PA}=79$ & 94 & 99 & 86 & $77^{*}$ & 69 \\
\hline IRBP & 1,9 & $\begin{array}{l}\text { Schneider } \text { et al. } \\
1996\end{array}$ & $\mathrm{PC}=96$ & 99 & 100 & 77 & 100 & $84^{* *}$ \\
\hline G6PD & 1,2 & $\begin{array}{l}\text { Von Dorman \& } \\
\text { Ruvolo, } 1999\end{array}$ & $\mathrm{AC}=40$ & 83 & 78 & 72 & 100 & 80 \\
\hline $\mathrm{B} 2 \mathrm{M}$ & 1,7 & $\begin{array}{l}\text { Canavez et al. } \\
\text { 1999a }\end{array}$ & $\mathrm{PA}=72$ & 56 & 87 & 96 & 100 & 92 \\
\hline vWF & 0,7 & $\begin{array}{l}\text { Chaves et al. } \\
1999\end{array}$ & & & & & 98 & 84 \\
\hline $\begin{array}{l}\text { EPSILON and } \\
5 \text { ' region }\end{array}$ & $\begin{array}{c}1.8 \text { to } \\
4.3\end{array}$ & $\begin{array}{l}\text { Porter et al. } \\
1997 \mathrm{a}\end{array}$ & $\mathrm{PAC}=100$ & 100 & & & & \\
\hline $\begin{array}{l}\text { EPSILON } \\
\text { 5' region }\end{array}$ & $\begin{array}{c}1.2- \\
1.4\end{array}$ & $\begin{array}{l}\text { Porter et al. } \\
1999\end{array}$ & & & 100 & & & \\
\hline ND4, tRNAs & 0,8 & $\begin{array}{l}\text { Pastorini et al. } \\
1998\end{array}$ & & & & & $81^{*}$ & 80 \\
\hline $\begin{array}{l}\text { Gamma- } \\
\text { Globin }\end{array}$ & 9,6 & $\begin{array}{l}\text { Meireles et al. } \\
1999\end{array}$ & & & & 100 & & \\
\hline
\end{tabular}

BS: Bootstrap Support. Bootstrapping involves creating a new data set by sampling N characters randomly with replacement, so that the resulting data set has the same size as the original, but some characters have been left out and others are duplicated. The random variation of the results from analyzing these bootstrapped data sets can be shown statistically to be typical of the variation that you would get from collecting new data sets (Felseinstein, 1985).

$\mathrm{PA}=$ Pitheciines $\times$ Atelines $; \mathrm{PC}=$ Pitheciines $\times$ Cebids $; \mathrm{AC}=$ Atelines $\times$ Cebids $;$ PAC $=$ unresolved trichotomy

* Saguinus and Leontopithecus as sister group

** Callimico and Leontopithecus as sister group of Callithrix

ateline-pitheciine clade, but the bootstrap support is not strong (78\%) in the MP tree. In addition, Porter et al. (1997b)'s analysis using 5'upstream region of epsilon gene in selected primates taxa showed the three major clades in an unresolved trichotomy. The poor resolution of the phylogenetic reconstruction of the three major platyrrhine lineages, resulting from the most robust molecular dataset so far available for the New World monkeys, strongly suggests that the pitheciines, atelines and cebids emerged at almost the same time in the platyrrhine radiation. These lineages are named by Schneider et al. 1996, Schneider \& Rosenberger 1996 and Goodman et al. 1998, as the Atelidae, Pitheciidae and Cebidae fam- ilies.

In the Pitheciidae family the four nuclear genes and the joint DNA analysis significantly placed $\mathrm{Cal}$ licebus as a sister group of the traditional pitheciines, Pithecia, Chiropotes and Cacajao (bootstrap values ranging from 78 to $100 \%$ ). These results were reinforced by the complementary study of Porter et al. (1999) encompassing more than $4 \mathrm{~Kb}$ of the epsilon globin gene and its upstream region.

The joint analysis strongly supports the monophyly of the Cebidae family, grouping Aotus, Cebus, and Saimiri with the small callitrichines (bootstrap values from 83 to $100 \%$ ). Additionally, three of the four nuclear genes (IRBP, G6PD, $\beta$-2M), and 


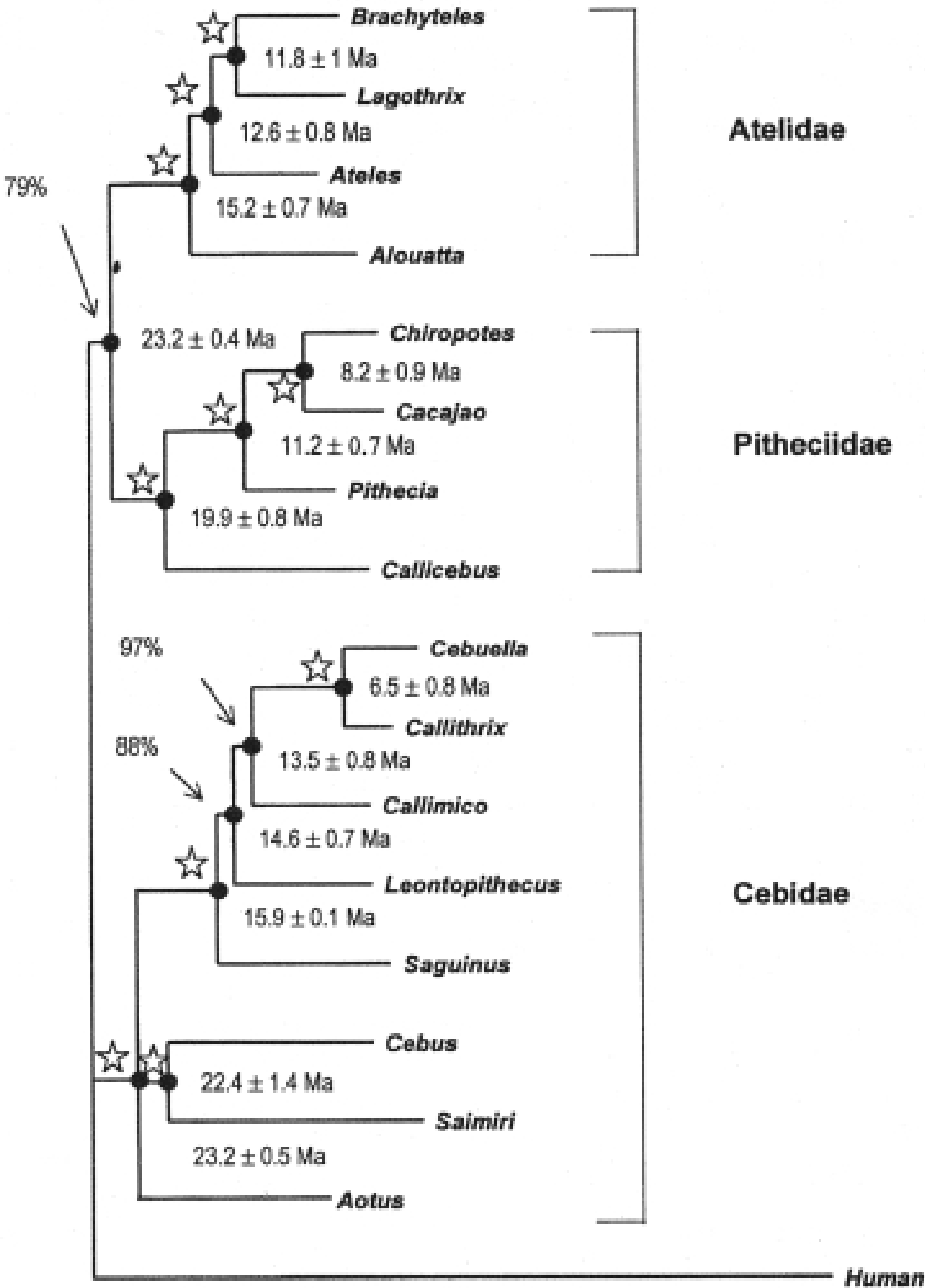

Fig. 1 - Phylogenetic tree found for the 17 sequences of the $\beta 2-M$, EPSILON, G6PD and IRBP genes aligned in tandem. Branch lengths and standard deviations were estimated based on leastsquares method described in Takezaki et al. (1995). Divergence times were estimated using the local molecular clock strategy as described in Schneider et al. (1993). MP Bootstrap values at the nodes were obtained in 1000 replicates. Stars at nodes means BS of 99-100\%. The length and Consistency index of the MP tree was 2855 and 0.83 , respectively. 
the epsilon upstream region of Porter et al. (1997a, 1999) also indicate a close relationship between $\mathrm{Ce}$ bus and Saimiri. Among the callitrichines, additional molecular data of Pastorini et al. (1998) using mitochondrial DNA; Chaves et al. (1999), Canavez et al. (1999a b), using nuclear DNA (intron 11 of von Willebrand, $\beta$-2-microglobulin genes), strongly supported the reclassification of Cebuela as belonging to the Callithrix genus (See also Porter et al. 1997b, Barroso et al. 1997) and also significantly placed Callimico as a sister group of Callithrix, contrary to the traditional view of Callimico as being basal to the callitrichines. Five of the six genes, and the joint analysis placed Saguinus as the basal genus of the callitrichine tree with significant bootstrap values (98-100\%). Finally, four nuclear genes and the joint analysis showed a congruent branching pattern in the atelid clade, placing Alouatta as the most basal lineage and Brachyteles from the Atlantic forest) and Lagothrix (from the Amazonian forest), as sharing the last common ancestor (bootstrap values ranging from 78 to $100 \%$ ), contrasting to the widely disseminated view that Ateles and Brachyteles share the last common ancestor in the ateline clade. Furthermore, as shown in Table I, the investigation by Meireles et al. (1999), encompassing more than $9 \mathrm{~Kb}$ of the gamma globin gene complex strongly supports the Lagothrix-Brachyteles clade (bootstrap value of 100\%).

If, at the intergeneric level, the phylogenetic ties are almost elucidated, the same does not occur at the subgeneric level. In almost all polyspecific genera, the relationships among species are highly controversial. The callitrichines are the most investigated group until now at the intrageneric level. In the Callithrix genus there are two well defined groups: a jacchus group with an eastern geographic distribution (Atlantic forest), and an argentata group from the Amazonian region. DNA data from Tagliaro et al. (1997), Chaves et al. (1999) and Canavez et al. (1999a b), suggest that the Amazonian Callithrix pygmaea and C. argentata are closely related species, as expected in view of their geographic dis- tribution. On the other hand, the molecular data does not support the recognition of the Amazonian C. humeralifera and the recently described species C. mauesi as distinct taxa (Tagliaro et al. 1997). Furthermore, in the jacchus group, which has a high diversity of morphotypes, Tagliaro et al. (1997) using highly variable mitochondrial DNA data, found that the C. jacchus, C. kuhli, C. penicillata, and $C$. geoffroyi species are very similar and that $C$. aurita is the earliest branch of the Atlantic forest group. In addition, the genetic divergence values between species of the Callithrix genus are very small, suggesting that speciation in this group is a very recent event.

\section{THE AGES OF THE PLATYRRHINE CLADES}

Following Avise \& Johns (1999), divergence times were used to construct a provisional age-related classification of the New World monkeys (Table II). Using the catarrhine-platyrrhine split at $40 \mathrm{Ma}$ (Mega annum) in the middle Eocene, according to Goodman et al. $(1998,1999)$, we estimate that the platyrrhine families, as total groups (Total groups includes all members of the crown group, the stem of the last common ancestor (LCA) and all extinct taxa) originated in the middle to late Oligocene epoch at $26 \mathrm{Ma}$.

According to our estimates, based on the joint molecular analysis of the combined nuclear genes and calibrating the molecular clock for the emergence of the families at the Oligocene-Miocene boundary (26 Ma), it appears that the Cebidae family split into the subfamilies Cebinae Aotinae at 22$23 \mathrm{Ma}$, each one with single extant monogeneric tribes (Cebini for Cebus and Aotini for Aotus). In the early to middle Miocene (16-13 Ma), the basal callitrichines branched into monogeneric subtribes Saguinina (Saguinus), Leontopithecina (Leontopithecus), Callimiconina (Callimico), and Callitrichina (Callithrix).

According to our proposal, all the members of the Pitheciidae family are grouped in a single subfamily, Pitheciinae, that split at $19 \mathrm{Ma}$ into two 


\section{TABLE II}

\section{Provisional age-related New World monkeys Classification}

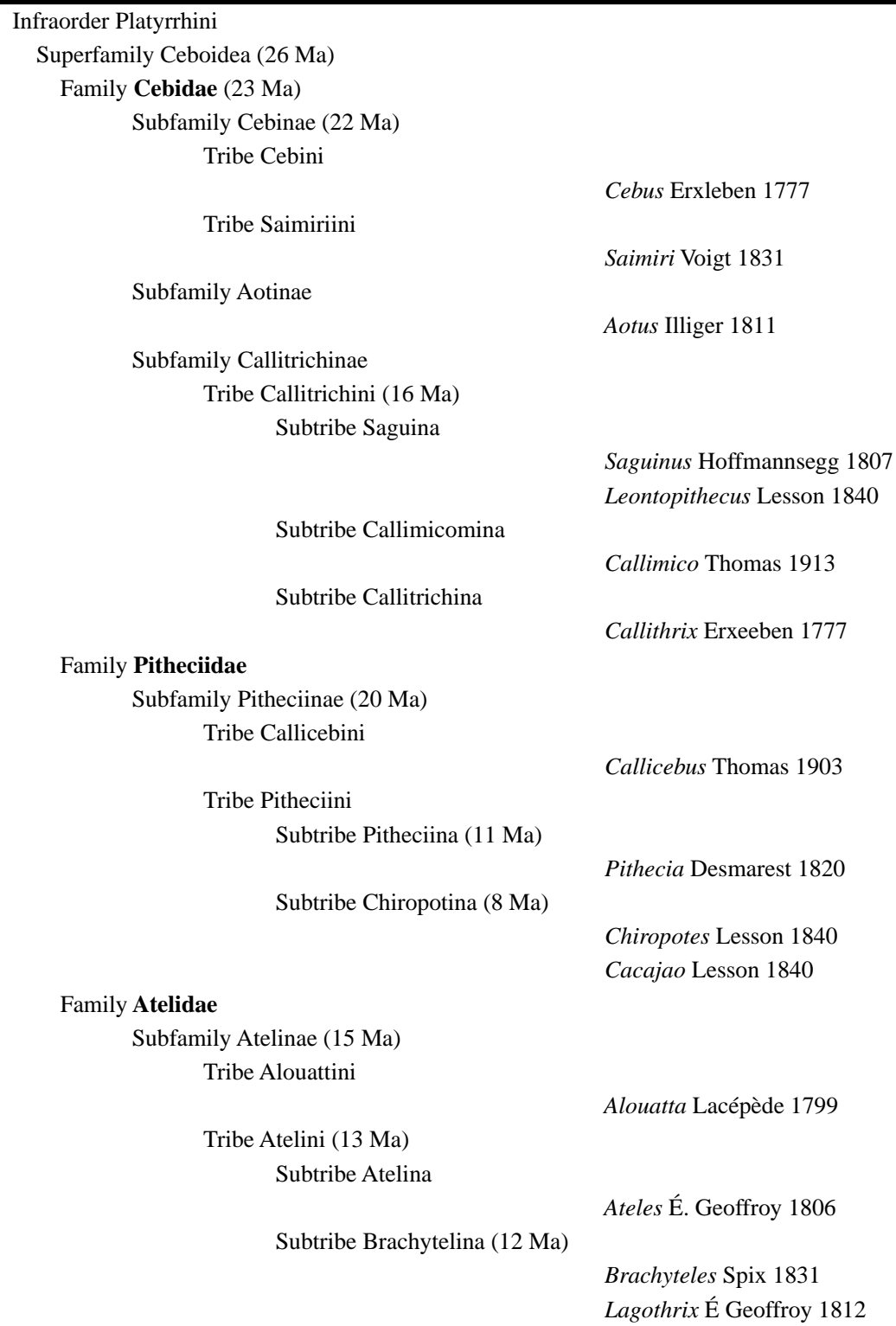

tribes: the monogeneric Callicebini, with the subtribe Callicebina (Callicebus), and the Pitheciini with two subtribes, Pitheciina (Pithecia) and Chiropotina (Chiropotes and Cacajao).

For the Atelidae family, we estimate that at about $15 \mathrm{Ma}$ the early atelines divided into two tribes: Alouattini (genus Alouatta) and Atelini, this later tribe splitting in the middle to late Miocene (13 Ma) into two subtribes, Atelina (Ateles) and Brachytelina (Lagothrix and Brachyteles).

The branching events suggested for the Pitheciidae and Atelidae families are in agreement with fossil data. The existence of Stirtonia, Cebupithecia, and Nuciruptor fossils (related to Alouatta, pitheci- 
ines and a sister group of pitheciines, respectively) in the middle Miocene scenario, indicates that the stem lineage of pitheciines and atelines were present at that time (Horowitz 1999). However, additional reliable fossil data are necessary to illuminate several other branching points in the New World monkey phylogenetic tree.

In summary, three evolutionary lineages are strongly established for the New World monkeys: atelines, pitheciines, and cebids. However, two major points regarding the branching patterns of the most ancient lineages remain to be clarified: (i) what is the exact branching pattern of Aotus, Cebus, Saimiri and the small callitrichines?; and (ii), which two of these three lineages, pitheciines, atelines or cebids, are more closely related?

On the other hand, at the subgeneric level, all the platyrrhine genera deserve to be well investigated. Our preliminary estimates indicate that the majority of the speciation processes seem to have occurred in the Pliocene-Pleistocene scenario (5 Ma or less). However, because the internodes are usually very small when species and populations are compared, even using highly variable mitochondrial DNA, to better understand the recent evolutionary processes of the New World monkeys, a global approach using geomorphology, biogeography, traditional morphology, behavior and cytogenetics, in association with DNA sequencing, should be advocated.

\section{ACKNOWLEDGEMENTS}

I would like to thank Dr. Iracilda Sampaio and Dr. Colin Beasley for critical reading of the manuscript. I am also grateful to Dr. Miranda van Dorman and Hector Seuanez for providing the G6PD and $\beta 2$ $\mathrm{M}$ alignments. This work was supported by grants from UFPA, CNPq, FINEP, FADESP.

\section{REFERENCES}

Avise JC \& Johns GC. 1999. Proposal for a standartized temporal scheme of biological classification for extant species. Proc Natl Acad Sci USA 96: 73587363.

Barroso CML, Schneider H, Schneider MPC, SAMpaio I, Harada ML, Czelusniak J \& Goodman M. 1997. Update on the phylogenetic systematics of New World monkeys: further evidence for placing the pygmy marmoset Cebuella) within the genus Callithrix. Int J Primatol 18: 645-668.

Canavez FC, Moreira MaM, Simon F, Parham P \& Seuanez HN. 1999b. Phylogenetic Relationships of the Callitrichinae (Platyrrhini, Primates) Based on $\beta 2$-Microglobulin DNA sequences. Am J Primatol 48: $225-236$.

Canavez FC, Moreira MaM, Ladoski JL, Pissinati A, Parhan P \& Seuanez HN. 1999a. Molecular Phylogenetics of New World primates (Platyrrhine) based on $\beta 2$-Microglobulin DNA Sequences. $\mathrm{Mol}$ Phylogenet Evol 12: 74-82.

Chaves R, Sampaio I, Schneider MPC, Schneider H, Page SL \& Goodman M. 1999. The place of $\mathrm{Cal}$ limico goeldii in the Callitrichine phylogenetic tree: Evidence from von Willebrand Factor Gene Intron II Sequences. Molecular Phylogenet Evol 13: 392404.

Felseinstein J. 1985. Confidence limits on Phylogeny: An approach using the bootstrap. Evolution 39: 783791.

Ford SM. 1986. Systematics of the New World monkeys. In: Comparative Primate Biology, Volume I: Systematics, Evolution and Anatomy (DR SwINDLER \& J Erwin, Eds.) pp 73-135 Alan R. Liss, New York.

Goodman M. 1999. Molecular Evolution 99. The genomic Record of Humankind's Evolutionary Roots. Am J Human Genet 64: 31-39.

Goodman M, Porter CA, Czelusniak J, Page SL, Schneider H, Shoshani J, Gunnell G \& Groves CP. 1998. Toward a phylogenetic classification of primates based on DNA evidence complemented by fossil evidence. Mol Phylogenet Evol 9: 585-598.

Hershkovitz P. 1977. Living New World Monkeys, Part 1 (Platyrrhini), with an Introduction to Primates. Chicago: Chicago University Press. 
Horowitz I. 1999. A phylogenetic study of living and fossil Platyrrhines. Am Mus Novitates 3269: 1-40.

KAY RF. 1990. The phyletic relationships of extant and fossil Pitheciinae (Platyrrhini, Anthropoidea). J Human Evol 19: 175-208.

Meireles CM, Czesluniak J, Schneider MPC, Muniz JAPC, Brigido MC, Ferreira HS \& Goodman M. 1999. Molecular Phylogeny of Ateline New World Monkeys (Platyrrhini, Atelinae) Based on (-Globin Gene Sequences: Evidence that Brachyteles is the sister group of Lagothrix. Mol Phylogenet Evol 12: 10-30.

Pastorini J, Forstner MRJ, Martin RD \& Melnick DJ. 1998. A Reexamination of the phylogenetic position of Callimico (Primates) incorporating new mitochondrial DNA sequence data. J Mol Evol 47: 32-41.

Porter CA, Czelusniak J, Schneider H, Schneider MPC, SAmpaio I \& Goodman M. 1997b. Sequences of the primate epsilon-globin gene: implications for systematics of the marmosets and other New World primates. Gene 205: 59-71.

Porter CA, Czelusniak J, Schneider H, Schneider MP, Sampaio I \& Goodman M. 1999. Sequences from the 5' flanking region of the epsilon-globin gene support the relationship of Callicebus with the pitheciins. Am J Primatol 48: 69-75.

Porter CA, Page SL, Czesluniak J, Schneider H, Schneider MPC, SAMPaio I \& Goodman M. 1997a. Phylogeny and Evolution of selected Primates as Determined by Sequences of the ,-globin locus and 5' flanking regions. Int J Primatol 18: 261-295.

Rosenberger AL. 1981. Systematics: the higher taxa. In: Ecology and behavior of neotropical Primates, Vol. 1 (AF CoImbra-Filho \& R Mitermeier, Eds.) pp 9-27 Acad Brasil Cienc, Rio de Janeiro.

Rosenberger AL \& Coimbra-Filho AF. 1984. Morphology, taxonomic status and affinities of the lion tamarins, Leontopithecus (Callitrichinae, Cebidae). Folia Primatol 42: 149-179.

Rosenberger AL, Setoguchi T \& Shigehara N. 1990. The fossil record of callitrichine primates. J Hum Evol 19: 209-236.
Saitou N \& Nei M. 1987. The neighbor-joining method: a new method for reconstructing phylogenetic trees. Mol Biol Evol 10: 1073-1095.

Schneider H \& Rosenberger AL. 1996. Molecules, Morphology, and Platyrrhine systematics. In: Adaptative Radiations of Neotropical Primates. MA NoRCONK, AL Rosenberger \& PA Garber (eds). Plenum Press, New York.

Schneider H, Schneider MPC, SAMPaio MIC, Harada ML, Stanhope M \& Goodman M. 1993. Molecular phylogeny of the New World monkeys (Platyrrhini, Primates). Mol Phylogenet Evol 2: 225-242.

Schneider H, Sampaio I, Harada ML, Barroso CML, Schneider MPC, Czelusniak J \& Goodman M. 1996. Molecular phylogeny of the New World monkeys (Platyrrhini, Primates) based on two unlinked nuclear genes: IRBP intron 1 and $\varepsilon$-globin sequences. Am J Phys Anthropol 100: 153-179.

Simons EL. 1972. Primate Evolution: An Introduction to Man'Place in Nature. MacMillan, New York.

Swofford DL. 1998. PAUP* Beta Version. Phylogenetic Analysis Using Parsimony (*and other Methods). Sinauer Associates, Inc. Publisher, Sundeland, Ma.

Tagliaro CH, Schneider MPC, Schneider H, SamPaio I \& Stanhope M. 1997. Marmoset phylogenetics, conservation perspectives, and evolution of the mtDNA control region. Mol Biol Evol 14: 674 684.

Takezaki N, Rzhetsky A \& Nei M. 1995. Phylogenetic Test of the Molecular Clock and Linearized Trees. Mol Biol Evol 12: 823-833.

Tejedor MF. 1998. La position de Aotus y Callicebus en la filogenias de los primatas platirrinos. Bol Primatol Lat 7: 13-29.

TYLER DE. 1991. The evolutionary relationships of Aotus. Folia Primatol 56: 50-52.

Von Dorman M \& Ruvolo M. 1999. Phylogenetic Relationships of the New World Monkeys (Primates, Platyrrhini) Based on Nuclear G6PD DNA Sequences. Mol Phylogenet Evol 11: 459-476. 